\title{
Privileging Power: Early Childhood Educators, Teachers, and Racial Socialization in Full-Day Kindergarten
}

\author{
Zuhra Abawi
}

Dr. Zuhra Abawi is an assistant professor of education at Niagara University, Ontario. Her work focuses on the ways that discourses of race and identity are negotiated, mediated, and socialized in education. Her research seeks to recenter the voices of racialized and Indigenous children, families, and educators by problematizing whiteness and Eurocentric developmentalist discourses and curricula embedded in educational institutions. Email: zabawi@niagara.edu

This paper critically unpacks the racialized and gendered hierarchies between the co-teaching model of early childhood educators (ECEs) and Ontario certified teachers (OCTs) in full-day kindergarten (FDK), and how such positionalities speak to racial socialization in early learning spaces. While young children and early learning spaces are often portrayed as raceless, ahistorical, and apolitical, extant literature suggests that children as young as two years of age are aware of visible and cultural differences between themselves and other groups. The paper employs a reconceptualist framework by drawing on critical race theory to explore how racialized power relations between ECEs and teachers inform hierarchies of dominance and impact processes of racial socialization in FDK learning spaces. While both professions are predominantly feminized, the overwhelming majority of teachers in Ontario are white and middle class, whereas ECEs in FDK programs are more likely to be racialized and marginalized due to low wages and diminished professional status as care workers rather than educators. Although there has been great emphasis on the importance of diversifying the teacher workforce, there is minimal study on the impact of the hierarchies and racialized power relations between ECEs and OCTs and their impact on racial socialization in FDK programs. This conceptual paper seeks to address this gap.

Key words: racialization; early childhood educators; Ontario certified teacher; full-day kindergarten
While there has been extensive research pertaining toward the importance of diversifying the teacher workforce in order to represent student diversity and provide equitable and inclusive education (e.g., Abawi, 2018; Abawi \& Eizadirad, 2020; James \& Turner, 2017; Ryan, Pollock, \& Antonelli, 2009; Turner Consulting Group, 2015), there is limited study on the racialized power relations informing the relationship between the coteaching team of early childhood educators (ECEs) and Ontario certified teachers (OCTs) within the full-day kindergarten (FDK) context. While both professions are predominantly feminized, the overwhelming majority of teachers in Ontario are white and middle class, whereas ECEs in FDK programs are more likely to be racialized and marginalized due to low wages and diminished professional status as care workers rather than educators. Dominant psychologicaldevelopmentalist discourses depict young children as too young to notice racial differences or engage with performances, negotiations, and mediations of racialization and identity. However, reconceptualist scholars counter such narratives and suggest that young children actively engage in meaning-making processes concerning race and identity (Iannacci \& Whitty, 2009; Lubeck, 1994; MacNaughton \& Davis, 2009; PaciniKetchabaw \& Nxumalo, 2013; Silin, 1995; Taylor, 2007). Moreover, young children hold positive and negative beliefs and dispositions about their own racial identity as well as other races (Escayg, 2019). Dominant developmentalist paradigms depict and frame children and families through surveillance practices in accordance with 
predetermined developmental milestones that often pathologize and other racialized and Indigenous children and families (Abawi \& Berman, 2019). Although young children are often constructed as too young to understand and engage with racial differences, they are constantly receiving racially coded messages embedded not only in classroom materials, curriculum, representation and resources, but also in interactions between educators and children and between OCTs and ECEs, whereby teachers hold considerably more power in terms of classroom decisions and programming than ECEs (Daniel \& Escayg, 2019). ECEs are significantly more likely than teachers to be involved in precarious work, which is both gendered and racialized. The dichotomies between teachers and ECEs are perpetuated by highly stratified roles, statuses, salaries, and education (Abawi, Berman, \& Powell, 2019; Hossein, 2014).

This paper considers how racial socialization transpires in Ontario's FDK program against the backdrop of the power relations and dichotomies that frame the relationality between OCTs and ECEs. Racial socialization refers to the direct or indirect messages that are transmitted about race and racial differences through various mediums, including the media, education, and family or upbringing (Gaskin, 2015). Ontario is often touted as the most ethno-racially diverse region in the world, with the largest share of immigrants and refugees in Canada (Statistics Canada, 2016). Moreover, over a quarter of Ontario's demographic is racialized, with Indigenous communities the fastest growing demographic in Canada (Statistics Canada, 2016). When I use the term racialized, I am referring to people of non-European heritage, regardless of whether they are Canadian born or not (Statistics Canada, 2016). I intentionally separate the term Indigenous from racialized to avoid conflation of the terms. While school boards are not required to collect demographic-based data, studies (e.g., Abawi, 2018; Abawi \& Eizadirad, 2020; Turner Consulting Group, 2015) suggest that the Ontario teacher workforce has not kept pace with student demographics and is largely white and middle class. ECEs working in FDK are confined to precarious employment, devalued labour, and low wages, all of which disproportionately affect racialized and Indigenous communities. My interest in this topic stems from my experience having been both an OCT and an ECE working in the FDK program in both roles. I identify as white passing of mixed race; my father is Afghan and my mother is Scottish. The paper is divided into the following sections: an overview of the FDK program; reconceptualizing and racializing childhood; race and FDK; and discussion and conclusion.

\section{Reconceptualizing and racializing childhood}

The reconceptualist movement in early childhood education materialized in the late 1980s and provided an epistemic shift that decentered traditional psychological-developmentalist conceptions of children and childhoods through a multidisciplinary framework (Bloch, Swadener, \& Cannella, 2014). Hegemonic narratives of psychological development framing children and childhoods have widely been narrated as ahistorical, apolitical, colour blind, and neutral, all of which have become normalized in early childhood pedagogies, curricula, and policies (Abawi \& Berman, 2019; Iannacci \& Whitty, 2009; Pacini-Ketchabaw \& Nxumalo, 2013).

These dominant discursive practices have been largely based on scholarship and studies completed by and with white, able-bodied, cis-gendered scholars, children, and families. Reconceptualists thus recenter multifaceted lived experiences and ways of knowing to counter dominant paradigms. Reconceptualist scholarship, while important and much needed to shift away from dominant developmental discourses, remains largely conceptualized from a white onto-epistemological positioning (see Perez, Saavedra, \& Habashi, 2017). The most notable concept of the traditional psychological-developmental framework is developmentally appropriate practice (DAP), developed and promoted by the (American) National Association for the Education of Young Children. Reconceptualist scholars dismantle DAP by problematizing the ways it others minoritized children, families, and communities, ascribing standardized trajectories of human development and milestones that privilege children who meet these 
standards and pathologize children and families who do not (Abawi \& Berman, 2019; Brown, Souto-Manning, \& Tropp Laman, 2010; Lubeck, 1994; MacNaughton \& Davis, 2009; Pacini-Ketchabaw, Nxumalo, \& Rowan, 2011). DAP, which ascribes learning goals, outcomes, and expectations in accordance with age, fails to consider children's diverse needs, variations, and lived experiences (Escayg, 2019). Scholars who draw on a CRT approach deconstruct concepts such as DAP as racially coded terms weaponized to track, document, and enforce conformity on children according to dominant developmentalist norms that are informed by whiteness, without room for counternarratives or other possibilities of conceptualizing children and childhoods.

Reconceptualist frameworks center on power relations by interrogating which bodies, identities, and ontological dispositions are privileged and which are oppressed by a developmentalist narrative. This paradigm provides a conceptual framework to consider how hierarchical and raced relations between ECEs and OCTs in settler colonial educational spaces such as FDK operate, materialize, and subsequently normalize racialized labour power relations between the two roles.

\section{Race-ing ECEs and OCTs}

Ontario was the first province to initiate the FDK program, a co-teaching model that combines the expertise of a registered ECE and an OCT. The implementation of FDK for 4- and 5-year-old children provided a more comprehensive early learning strategy, one that is publicly funded and which offset the financial burden of childcare fees from families to the provincial government (Gananathan, 2015). The co-teaching model of OCTs and ECEs was meant to provide a collaborative approach that would merge a play-based ECE focus with an OCT curricular and "educational" focus. OCTs and ECEs were contextualized as equal partners in teaching through the FDK model. On the one hand, the FDK program raised the status of ECEs through the establishment of the College of Early Childhood Educators (CECE), in which the designation of registered ECE became a protected professional title. The CECE is the first professional regulatory body for ECEs in Canada. It established a code of ethics and standards of practice similar to those of the Ontario College of Teachers (Association of Early Childhood Educators Ontario, 2016). On the other hand, while ECEs obtained professionalization, their equal status as partners with OCTs in the classroom is fundamentally untrue. Although both the teaching and ECE professions are characterized by feminization, OCTs have been discursively characterized as educators, while ECEs have been framed as care workers within a neoliberal context that devalues care work (Langford, Powell, \& Bezanson, 2020; Richardson et al., 2013).

Moreover, the binaries between ECEs and OCTs in FDK are highlighted by ECEs' poor working conditions, characterized by job precarity, lack of recognition and value for their work, and limited opportunities for income and professional growth. The precarious status of ECEs in school boards is characterized by hourly contracts, unpaid summer vacations, and limited job security, as their job permanence depends on the enrollment rates of 4and 5-year olds (Abawi, Berman, \& Powell, 2019). Finally, many ECEs are required to take on split shifts between different schools, requiring them to travel, often long distances, from one school to another, whilst losing break and planning times (Abawi et al., 2019; Association of Early Childhood Educators Ontario, 2016; Ganananthan, 2015; Moss, 2006). Further, while teacher pay increases with years of service, ECE pay remains relatively stagnant, further widening income and opportunity gaps between OCTs and ECEs. ECE testimonies speak to feelings of being undervalued as an assistant to the teacher, with differing working conditions and an overall lack of respect from parents and colleagues toward their role (Gibson \& Pelletier, 2016). Racialized communities are overrepresented in precarious employment, such as within the early childhood education and care (ECEC) sector, and they experience income and earning gaps; racialized earning gaps between white and nonwhite Ontarians are at an all-time peak (Colour of Poverty, 2018; United Way, 2019). 
While publicly funded school boards are not required to collect demographic-based data, extant research suggests that Ontario teachers are overwhelmingly white and middle class and have not kept pace with the increasing diversity of students in Ontario classrooms (Abawi, 2018; Abawi \& Eizadirad, 2020; Ryan, Pollock, \& Antonelli, 2009; Turner Consulting Group, 2015). Ontario has repeatedly been called to diversify its teacher workforce; many of its policies pertaining to hiring for diversity are based on bias-free hiring approaches as best practice for closing the teacher diversity gap (Abawi, 2018). The power relations between predominantly white, middle-class OCTs as educators and precarious, poorly paid ECEs as caregivers, although both are gendered, are also racially stratified. The racial socialization of young children in FDK is permeated by the dichotomies between OCTs and ECEs, which transmit messages about whose bodies can hold authority, power, and control and whose bodies are subjected into submission. Differences in salary and professional status in the school community are often correlated to educational background, whereby OCTs are required to have a three- or four-year undergraduate degree and ECEs must complete an early childhood education program, most commonly an Ontario college diploma (Gibson \& Pelletier, 2011; Hossein, 2014). The binaries between teachers and ECEs are manifested in the privileges afforded to teachers in terms of decision making, programming, and assessment practices. The polarization of the two roles others ECEs as having less autonomy, less power, poorer working conditions, and limited status within the school community (Abawi et al., 2019; Gibson \& Pelletier, 2011; Hossein, 2014).

\section{Critical race theory}

Critical race theory (CRT; Crenshaw, 2011; Delgado \& Stefancic, 2017; Ladson-Billings, 1998; Matias et al., 2014; Sleeter, 2017) problematizes narratives of colour-blindness often perpetuated in early learning curricula (Bonilla-Silva, 2003, 2006). The concept of colour-blind neutrality conjures up discourses of a postracial society in which racism is a phenomenon of the past and not an ongoing systemic, structural, and institutional barrier for racialized and Indigenous communities. CRT acknowledges that intersecting social identities such as gender and race must be contemplated when exploring processes of racial socialization to consider the myriad ways that multiple positionalities structure power relations (Crenshaw, 2011). Scholar Gloria Ladson-Billings (1999) outlines the four pillars of CRT as follows: (1) attention to the normalization of racism in society; (2) storytelling as a counternarrative to white dominance; (3) the critique of liberalism where systems of racism and racialization are silenced; and (4) an emphasis on race realism. CRT challenges racism and processes of racialization by centering these processes and thus dismantling neutrality and colour-blindness. Research using a CRT framework is often focused on $\mathrm{K}-12$ and postsecondary education; CRT is an important lens to reconceptualize race and racialization in early childhood spaces (Berman et al. 2017; Bryan, 2018; MacNevin \& Berman, 2017). A fundamental tenet of CRT is storytelling as a counternarrative. Stories provide space for racialized and Indigenous communities to provide perspectives of historical and ontological experiences of racialization. Ladson-Billings (1998) highlighted the importance of counternarratives as resistance to dismantle white experiences as the norm. Personal narratives provide a critical and transformational practice through "the naming of one's own reality with stories that can affect the oppressor" (p. 14). CRT speaks to the ways in which ECEs' knowledge, skills, and experiences are marginalized and their roles in the FDK program are ambiguous within the larger school community. CRT provides space for counternarratives that allow ECEs to be valued and contributing members of the FDK teaching team.

Under the dominant developmentalist lens of childhood and children, racial socialization is minimized and dismissed as inappropriate. Thus, young children are socialized to not talk about race and to pretend not to notice differences between people, especially differences of those who do not conform to social norms (DiAngelo, 2018). The widespread assumption that children are blind to racial differences is rooted in reductionary Western epistemologies of child learning and development which assert that children are too incompetent to understand, engage with, and navigate race and identity (di Tomasso, 2012). The psychological-developmentalist paradigm 
that frames children as helpless and oblivious to race is underlined in numerous studies that posit that many preservice teachers and ECEs alike do not notice race or racism as issues in their learning environments and thus perpetuate colour-blind dispositions toward children, families, and communities (Berman et al., 2017; Han, 2013; MacNaughton \& Davis, 2009). A critical race lens supports an understanding of the gendered and racialized hierarchies that constitute the positionalities of OCTs and ECEs, one group privileged and included in the school community and the other precarious and excluded. Young children in FDK receive such messages concerning gendered and racialized inclusion and exclusion, which assist in shaping their norms and perceptions about power and privilege.

\section{Race and children in full-day kindergarten}

Early learning spaces must be reconceptualized and reimagined as contested sites of cultural and social reproduction and transmission within a settler colonial context such as Ontario (Butler \& Teasley, 2019). While text as policy or curriculum is never neutral but is permeated by power relations, embodiment and subjectivity are pivotal to teaching and learning. Marginalized families and children are often subjected to multiple forms of ethnocentric oppression, such as pedagogies that privilege whiteness at the expense of non-Eurocentric epistemologies. Curricular approaches such as Ontario's kindergarten program (Ontario Ministry of Education, 2016) fail to engage children in critical discussions, pedagogies, and practices that center power relations, race, racialization, and whiteness (Escayg, 2019). When incidents of racism emerge in early learning spaces, they are often minimized or downplayed and overwhelmingly unreported (Berman et al., 2017). Studies suggest that children of all races hold pro-white biases and that educators of young children in fact reinforce stereotypes by enacting colour-blind and neutral approaches toward incidents of racism and performances and mediations of race and identity (Boutte, 2008; MacNaughton \& Davis, 2009; MacNevin \& Berman, 2016). Therefore, it is important to consider how intersectionalities of oppression are perpetuated as status quo within FDK hierarchies, such as the hierarchies of power between teachers and ECEs, and how these racially coded messages impact young children's engagement with racial socialization.

Many of the colour-blind narratives that inform curricular and pedagogical practices have their roots in the USbased Derman-Sparks Anti-Bias Curriculum (1989). The anti-bias curriculum reinforced positive views of diversity and recognizing differences as a mechanism to strengthen social cohesion in multicultural societies. However, the anti-bias curriculum framed diversity from a Eurocentric developmentalist lens while simultaneously glossing over any dialogue on the impact of power relations on social constructs of racial identity (Escayg, Berman, \& Royer, 2017; Friendly \& Prentice, 2009; Vandenbroeck, 2010). Ontario’s kindergarten program (Ontario Ministry of Education, 2016) is the curricular document that informs pedagogical and assessment practices in the FDK program. The kindergarten program mentions the word race on two occasions, the first in the introductory section of the document as a footnote in reference to the Ministry of Education's Achieving Excellence: A Renewed Vision for Education in Ontario (2014). The second time race is mentioned is under section 3.1 "Equity and Inclusive Education in Kindergarten," which generically notes:

In an environment based on the principles of inclusive education, all children in kindergarten, their parents, other family members, and other members of the school community-regardless of ancestry, culture, ethnicity, sex, physical or intellectual ability, race, religion, gender identity, sexual orientation, socio-economic status, or other similar factors-are welcomed, included, treated fairly, and respected. Diversity is valued and all members of the school community feel safe, comfortable and accepted. (Ontario Ministry of Education, 2016, p. 101)

Although race and diversities of social location are mentioned in the kindergarten program, the document provides 
an all-encompassing statement that proclaims that all communities are welcomed and included, speaking on behalf of those communities and thus speaking over the myriad lived experiences and positionalities of marginalized communities. The statement moreover conceals the power imbalances between teachers and ECEs by emphasizing the role of colour-blindness and discourses of "racial innocence" (Escayg, 2019) that speak to the dominant framing of young children's understandings and encounters of and with racialization. While there has been a shift in discourse from multiculturalism and equality to equity and inclusion, the narratives pertaining to difference and diversity are constructed from an anti-bias paradigm (Segeren, 2016). Moreover, the curriculum does not discuss issues of race, racism, or discrimination, and it conforms to Eurocentric psychological-developmentalist discourses of children and childhood. The curriculum embedded in FDK is insufficient for decentering white privilege or the pervasive developmentalist norms permeated in early childhood epistemological norms and practices (Berman et al., 2017; Pacini-Ketchabaw, Nxumalo, Kocher, Elliot, \& Sanchez, 2015).

Education in Canada is a provincial responsibility, and thus there is no federal oversight to ensure coherence between the provinces and territories (Robertson \& Doyle-Jones, 2015; Simpson, James, \& Mack, 2011). The omission of a cohesive federal ECEC policy framework is also evident as ECEC policies are responsibilities designated to the provinces to establish their own policy priorities. However, as it stands, Ontario, as Canada's most diverse province, lacks an ECEC policy to ensure the proposed commitment to equity, inclusion, and social justice translates into pedagogical action rather than diversity "happy talk" whereby diversity becomes an increasingly prevalent talking point without critical action (Ahmed, 2012). As Robertson and Doyle-Jones (2015) note, there is a competing policy agenda enveloping early childhood learning in Ontario. The agenda places the dominant initiative of highquality programming and safety in conflict with policies of equity and inclusion, and high-quality programming with its focus on child development milestones takes precedence. Berman et al. (2017) contend that ECEs in the Anglosphere might perpetuate racism and processes of racialization through colour-blind interactions and practices.

Current policy and curricular definitions of equity and inclusion are articulated in such a manner that they shall never materialize into more than "laminated equity" (Lopez, 2013) as there is no naming of race and racism. Rather, the kindergarten document (Ontario Ministry of Education, 2016) encourages a gentle self-reflexive approach that offers no accountability to addressing or removing systemic, institutional, and structural barriers encountered by racialized families, educators, and communities. A CRT analysis makes racialization and intersectionalities of identity salient in narratives about children, childhoods, families, curriculum, materials, and relationships between educators and students as well as educators themselves. The lack of acknowledgement of the inequitable power structures within policy documents highlights the dichotomies between OCTs and ECEs in FDK programs. The exclusion of ECE epistemologies, contributions, and experience are often subjugated by the privileging of teacher's educational qualifications, decision-making and professional status within the school and wider community. Teachers are often conceptualized as more powerful than ECEs and these hierarchical differences detrimentally impact the dynamic between OCTs and ECEs. These hierarchies are embedded in positionalities and intersectionalities of race, gender, and socioeconomic status and play out in the daily interactions between the two, while children in the classroom are constantly receiving messages and inferring meaning in relation to racial norms, representations, power, and oppression.

\section{Discussion and conclusion}

When considering how power relationships between ECEs, whose employment is characterized by precarity, devaluation of labour, and low wages-all of which are hallmarks of gendered and racialized labour-in comparison to overwhelmingly white, middle-class teachers, it is important to consider the implications such 
hierarchies have on the children in FDK spaces (Abawi, 2018; Escayg, 2019). Although Canada is conceptualized through dominant narratives of settler colonialism and as a place of opportunity for diversity and multiculturalism, racialized and Indigenous communities in Ontario and Canada are often denied access to the labour market (Galabuzi, 2006). This form of social exclusion manifests itself throughout the labour market through low-paying jobs and poor working conditions, employment precarity, and insecurity, all of which define the devaluation of the ECE profession in Ontario. Dominant relationships between ECEs and OCTs are fraught with intersectionalities of gender and race; these relationships are not neutral, ahistorical, or apolitical but socialized and embedded as a facet of white privilege in FDK learning environments. When considering racialized intersectionalities of power, such as race, gender, and economic precarity, it is critical to center on whiteness and white supremacy, whereby whiteness is an intact marker of racialized power (Bonilla-Silva, 2003). The benefits of racialized power manifest in systems of white supremacy, notably education in settler colonial contexts such as Ontario. Ansley (1997) defines white supremacy as "a political, economic, and cultural system in which whites overwhelmingly control power and material resources" (p. 599). The normalization of whiteness is perpetuated and embedded in white children's racial dispositions, beliefs, and attitudes toward themselves and nonwhite communities, in conjecture with prowhite biases among racialized children that are perpetuated and normalized through dichotomized interactions between ECEs and teachers (Escayg et al., 2017). As the majority of teachers in Ontario are white and middle class, these positionalities inform curricular delivery, classroom materials, assessment practices, and representation. The dominant positionality of teachers further normalizes white middle-class identities, while ECEs as precarious workers are undermined on the margins of the school community. The utilization of CRT reveals the gendered and racialized power relations that inform relationships and interactions between ECEs and OCTs in a manner whereby whiteness is always normalized and exerts power.

Racial socialization and meaning-making processes thus play out through hierarchical interactions between dominant white groups and nondominant racialized groups. Studies suggest that white Canadian children between the ages of 4 and 6 harbour positive attitudes toward their own racial identities and are significantly more likely to associate nonwhite groups with negativity (Aboud \& Doyle, 1995; Johnson \& Aboud, 2013). Racial meanings that privilege whiteness and white supremacy are compounded by the hierarchical racial power dichotomies that frame the relationship between ECEs and OCTs. These power relations speak to and send messages to young children in FDK programs about which bodies are afforded positions of authority, power, belonging, and control, as well as which bodies are deemed as "other" within the stratification of white supremacist settler colonial educational landscapes. Social identities such as race, gender, and socioeconomic status are therefore never neutral but are constructed through hierarchies in relation to white-settler normalcy, where narratives of citizenship and belonging are also intimately influenced (Abawi, 2018; Lopez, 2013). Dei (2003, 2007) posits the importance of educators in acknowledging the complexities of identity, noting "a key tenet is that educators must begin to understand their students through the lens of race as a salient part of their myriad identities" (2003, p. 3). When it comes to resisting the racialized and gendered power relations that are often manifested in the dichotomous relationship between OCTs and ECEs, there must be acknowledgement that children are not blind to such interactions. By employing a critical race and reconceptualist lens to rethink children and childhoods, one views children as constantly engaged in meaning-making processes, not only from messages of racialized socialization transmitted by the curriculum, materials, and resources, but also between teachers and ECEs. Providing space for ECEs to engage in counternarratives in order to share their wealth of knowledge and experience and become vital and equitable members of the school community is essential in order for administrators and teachers to understand the important role of ECEs in the FDK and larger learning communities. Well-meaning colour-blindness and apathy to race and positionality perpetuate whiteness as the status quo and oppress ECEs and nonwhite children, families, educators, and communities (Gay, 2010). As Ontario's racial diversity continues to grow, educational 
spaces in Ontario, such as FDK, must be reconceptualized as critical sites to resist, problematize, and deconstruct the racialized dichotomies, institutional, systemic, and structural inequities and relationships that privilege white dominance over othered bodies. 


\section{References}

Abawi, Z. (2018). Troubling the teacher diversity gap: The perpetuation of whiteness through practices of bias-free hiring in Ontario school boards [Doctoral thesis, University of Toronto]. TSpace Repository. https://tspace.library.utoronto.ca/bitstream/1807/82960/3/ Abawi Zuhra E 201803 EdD thesis.pdf

Abawi, Z., \& Berman, R. (2019). Politicizing early childhood education and care in Ontario: Race, identity and belonging. Journal of Curriculum, Teaching, Learning, and Leadership in Education, 4(2), 3-13. https://digitalcommons.unomaha.edu/cgi/viewcontent. cgi?article $=1075 \&$ context $=$ ctlle

Abawi, Z., Berman, R., \& Powell, A. (2019). Gender, race and precarity: Theorizing the parallels between early childhood educators and contract faculty in Ontario. Atlantis: Critical Studies in Gender, Culture and Social Justice, 40(1), 45-60. https://doi. org/10.7202/1066420ar

Abawi, Z., \& Eizadirad, A. (2020). Bias-free or biased hiring? Racialized teachers' perspectives on educational hiring practices in Ontario. Canadian Journal of Educational Administration and Policy, 193, 18-31. https://journalhosting.ucalgary.ca/index.php/cjeap/ article/view/68280

Aboud, F. E., \& Doyle, A. (1995). The development of in-group pride in Black Canadians. Journal of Cross Cultural Psychology, 26(3), 243-254. https://doi.org/10.11770022022195263002

Ahmed, S. (2012). On being included: Racism and diversity in institutional life. Duke University Press.

Ansley, F. L. (1997). White supremacy (and what we should do about it). In R. Delgado \& J. Stefancic (Eds.), Critical whiteness studies: Looking behind the mirror (pp. 592-595). Temple University Press.

Association of Early Childhood Educators Ontario. (2016). "I'm more that 'just' an ECE": Decent work from the perspective of Ontario's early childhood workforce. https://www.childcarecanada.org/sites/default/files/Im\%20more\%20than\%20just\%20an\%20ECE.pdf

Berman, R., Daniel, B. J., Butler, A., MacNevin, M., \& Royer, N. (2017). Nothing or almost nothing to report: Early childhood educators and discursive constructions of colourblindness. International Critical Childhood Policy Studies Journal, 6(1), 52-65. https:// journals.sfu.ca/iccps/index.php/childhoods/article/view/45

Bloch, M. N., Swadener, B. B., \& Cannella, G. S. (Eds.). (2014). Reconceptualizing early childhood care and education: Critical questions, new imaginaries and social activism: A reader. Peter Lang.

Bonilla-Silva, E. (2003). New racism, colorblind racism, and the future of whiteness in America. In A. W. Doane \& E. Bonilla-Silva (Eds.), White out: The continuing significance of racism (pp. 271-284). Routledge.

Bonilla-Silva, E. (2006). Racism without racists: Colorblind racism and the persistence of racial inequality in America (4th ed.). Rowman \& Littlefield.

Boutte, G. S. (2008). Beyond the illusion of diversity: How early childhood teachers can promote social justice. The Social Studies, 99(4), 165-173. https://doi.org/10.3200/TSSS.99.4.165-173

Brown, S., Souto-Manning, M., \& Tropp Laman, T. (2010). Seeing the strange in the familiar: Unpacking racialized practices in early childhood settings. Race Ethnicity and Education, 13(4), 513-532. https://doi.org/10.1080/13613324.2010.519957

Bryan, N. (2018): Shaking the bad boys: Troubling the criminalization of Black boys' childhood play, hegemonic white masculinity and femininity, and the school playground to-prison pipeline. Race Ethnicity and Education, 23(5), 1-16. https://doi.org/10.1080/136 $\underline{13324.2018 .1512483}$

Butler, A., \& Teasley, C. (2019). A decolonial, intersectional approach to disrupting whiteness, neoliberalism, and patriarchy in Western early childhood education and care. In P. Trifonas (Ed.), Handbook of theory and research in cultural studies and education (pp. $1-18)$. Springer.

Colour of Poverty. (2019). Factsheets. https://colourofpoverty.ca/fact-sheets/

Crenshaw, K. (2011). Twenty years of critical race theory: Looking back to move forward. Commentary: A commemoration. Connecticut 
Law Review, 43(5), 1253-1353. https://opencommons.uconn.edu/law review/117

Daniel, B. J., \& Escayg, K. A. (2019). "But, I don't believe it's about race": Challenging fallacies of race and racism amongst early childhood educators in Ontario. Journal of Curriculum, Teaching, Learning, and Leadership in Education, 4(2), 14-28. https:// digitalcommons.unomaha.edu/ctlle/vol4/iss $2 / 3 /$

Dei, G. S. (2003). Communicating across the tracks: Challenges for anti-racist educators in Ontario today. Orbit, 33(3), 2-5.

Dei, G. S. (2007). Integrative antiracism. Keynote address at "Multiculturalism With(out) Guarantees: The Integrative Anti-Racism Alternative," University of British Columbia, Vancouver, BC, April 2, 2007.

Delgado, R., \& Stefancic, J. (2017). Critical race theory: An introduction (3rd ed.). NYU Press.

Derman-Sparks, L. (1989). Anti-bias curriculum: Tools for empowering young children. National Association for the Education of Young Children.

DiAngelo, R. (2018). White fragility: Why it's so hard for white people to talk about racism. Beacon Press.

di Tomasso, L. (2012). Engaging with early childhood educators' encounters with race: An exploration of the discursive, material, and affective dimensions of whiteness and processes of racialization [Master's thesis, University of Victoria]. UVicSpace Repository. https://dspace.library.uvic.cal

Escayg, K. (2019). "Who's got the power?": A critical examination of the anti-bias curriculum. International Journal of Childcare and Education Policy, 13(6). https://ijccep.springeropen.com/articles/10.1186/s40723-019-0062-9

Escayg, K. A., Berman, R., \& Royer, N. (2017). Canadian children and race: Toward an antiracism analysis. Journal of Childhood Studies, 42(2), 10-21. https://doi.org/10.18357/jcs.v42i2.17838

Friendly, F., \& Prentice, S. (2009). About Canada: Childcare. Fernwood.

Galabuzi, G. (2006). Canada's economic apartheid: The social exclusion of racialized groups in the new century. Canadian Scholars Press.

Gananathan, R. (2015). Legal and policy implications for childhood professionals in Ontario's kindergarten programs [Doctoral thesis, University of Toronto]. TSpace Repository. https:/tspace.library.utoronto.ca/bitstream/1807/69316/3/Gananathan Romona_201506_PhD_thesis.pdf

Gaskin, A. (2015). Racial socialization: Ways parents can teach their kids about race. American Psychological Association, CYF News, August. https://www.apa.org/pi/families/resources/newsletter/2015/08/racial-socialization

Gay. G. (2010). Culturally responsive teaching: Theory, research, and practice ( $2^{\text {nd }}$ ed.). Teachers' College Press.

Gibson, A., \& Pelletier, J. (2011). Can we work together? Preliminary findings from an examination of ECE and teacher dynamics in fullday-early-learning kindergarten. http://www.oise.utoronto.ca/atkinson/UserFiles/File/SI2011_Poster_ECEandKteacher.pdf

Han, K. T. (2013). “These things do not ring true to me": Pre-service teacher dispositions to social justice literature in a remote state teacher education program. The Urban Review, 45(2), 143-166. https://doi.org/10.1007/s11256-012-0212-7

Hossein, R. (2014). Early childhood educator's perceptions of their roles and responsibilities in Ontario's full day kindergarten program [Master's thesis, Ryerson University]. Ryerson Digital Repository. https://digital.library.ryerson.ca/islandora/object/RULA\%3A6521

Iannacci, L., \& Whitty, P. (Eds.). (2009). Early childhood curricula: Reconceptualist perspectives (pp. 143-165). Brush Education Inc.

James, C. E., \& Turner, T. (2017). Towards race equity in education: The schooling of Black students in the greater Toronto area. York University.

Johnson, P. J., \& Aboud, F. E. (2013). Modifying ethnic attitudes in young children and the impact of communicator race and message strength. International Journal of Behavioural Development, 37(3), 182-191. https://doi.org/10.11770165025412466522

Ladson-Billings, G. (1998). Just what is CRT and what's it doing in a nice field like education? Qualitative Studies in Education, 1(11), 
102-118. https://doi.org/10.1080/095183998236863

Ladson-Billings, G. (1999). Just what is critical race theory and what's it doing in a nice field like education? In L. Parker, D. Deyhele, \& S. Villenas (Eds.), Race is ... race isn't: Critical race theory and qualitative studies in education (pp. 7-30). Westview Press.

Langford, R., Powell, A., \& Bezanson, K. (2020). Imagining a caring early childhood education and care system in Canada: A thought experiment. International Journal of Care and Caring, 4(1), 105-115. https://childcarecanada.org/documents/research-policypractice/19/10/imagining-caring-early-childhood-education-and-care-system

Lopez, A. E. (2013). Embedding and sustaining equitable practices in teacher's everyday work: A framework for critical action. Teaching and Learning, 7(3), 1-15. https://doi.org/10.26522/tl.v7i3.421

Lubeck, S. (1994). The politics of developmentally appropriate practice: Exploring issues of culture class and curriculum. In B. Mallory \& R. New (Eds.), Diversity and developmentally appropriate practices: Challenges for early childhood education (pp. 17-43). Teachers College Press.

MacNaughton, G., \& Davis, K. (2009). Discourses of "race" in early childhood: From cognition to power. In G. MacNaughton \& K. Davis (Eds.), Race and early childhood education: An international approach to identity, policies, and pedagogy (pp. 17-30). Palgrave Macmillan.

MacNevin, M., \& Berman. (2017). The Black baby doll doesn't fit the disconnect between childhood diversity policy, early childhood educator practice, and children's play. Early Childhood Development and Care, 187(5-6), 827-839. https://doi.org/10.1080/030 $\underline{04430.2016 .1223065}$

Matias, C. E., Vieska, K. M., Garrison-Wade, D., Madhavi, T., \& Galindo, R. (2014). "What is critical whiteness doing in OUR nice field like critical race theory?" Applying CRT and CRW to understand the white imagination of white teacher candidates. Equity and Excellence in Education, 47(3), 289-304. https://doi.org/10.1080/10665684.2014.933692

Moss, P. (2006). Structures, understandings, and discourses: Possibilities for re-envisioning the early childhood worker. Contemporary Issues in Early Childhood, 7 (1), 30-41. https://journals.sagepub.com/doi/pdf/10.2304/ciec.2006.7.1.30

Ontario Ministry of Education. (2014). Achieving excellence: A renewed vision for education in Ontario. http://www.edu.gov.on.ca/eng/ about/renewedVision.pdf

Ontario Ministry of Education. (2016). The kindergarten program. http://www.edu.gov.on.ca/eng/curriculum/elementary/kindergarten. $\underline{\mathrm{html}}$

Pacini-Ketchabaw, V., \& Nxumalo, F. (2013). Regenerating research partnerships in early childhood education: A non-idealized vision. In J. Duncan \& L. Conner (Eds.), Research partnerships in early childhood education: Teachers and researchers in collaboration (pp. 11-26). Palgrave Macmillan.

Pacini-Ketchabaw, V., Nxumalo, F., Kocher, L., Elliot, E., \& Sanchez, A. (2015). Journeys: Reconceptualizing early childhood practices through pedagogical narration. University of Toronto Press.

Pacini-Ketchabaw, V., Nxumalo, F., \& Rowan, C. (2011). Nomadic research practices in early childhood: Interrupting racisms and colonialisms. Reconceptualizing Educational Research Methodology, 2(1), 19-33. https://doi.org/10.7577/rerm.174

Perez, M. S., Saavedra, C. M., \& Habashi, J. (2017). Rethinking global north onto-epistemologies in childhood studies. Global Studies of Childhood, 7(2), 79-83. https://doi.org/10.11772043610617708875

Richardson, B., Langford, R., Friendly, M., \& Rahaula, A. (2013). From choice to change: An analysis of the "choice" discourse in Canada's 2006 federal election. Contemporary Issues in Early Childhood, 14(2), 155-167. https://www.researchgate.net/ publication/275684053 From Choice to Change An Analysis of the 'choice' Discourse in Canada's 2006 Federal Election

Robertson, L., \& Doyle-Jones, C. (2015). Pedagogies of difference: Equity and diversity in early childhood policy in Ontario. The International Journal of Holistic Early Learning and Development, 2, 64-76. 
Ryan, J., Pollock, K., \& Antonelli, F. (2009). Teacher diversity in Canada: Leaky pipelines, bottlenecks, and glass ceilings. Canadian Journal of Education, 32(3), 591-617. https://journals.sfu.ca/cje/index.php/cje-rce/article/view/3053

Segeren, A. (2016). How schools enact equity policies: A case study of social justice leadership [Doctoral dissertation, University of Western Ontario]. Western Graduate and Postdoctoral Studies, Electronic Thesis and Dissertation Repository. https://ir.lib.uwo.ca/ etd/4137/

Silin, J. G. (1995). Sex, death, and the education of our children: Our passion for ignorance in the age of AIDS. Teachers College Press.

Simpson, J. S., James, C. E., \& Mack, J. (2011). Multiculturalism, colonialism, and racialization: Conceptual starting points. Review of Education, Pedagogy, and Cultural Studies, 33(4), 285-305. https://doi.org/10.1080/10714413.2011.597637

Sleeter, E. (2017). Critical race theory and the whiteness of teacher education. Urban Education, 52(2), 99-110. https://doi. org/10.11770042085916668957

Statistics Canada. (2016). Immigration and ethnocultural diversity: Key results from the 2016 census. https://www150.statcan.gc.ca/n1/ daily-quotidien/171025/dq171025b-eng.htm

Taylor, A. (2007). Playing with difference: The cultural politics of childhood belonging. International Journal of Diversity in Organizations, Communities, and Nations, 7(3), 143-149. https://www.researchgate.net/publication/307134120 Playing with Difference The Cultural Politics of Childhood Belonging

Turner Consulting Group. (2015). Voices of Ontario Black educators: An experiential report. Ontario Alliance of Black School Educators. http://onabse.org/ONABSE VOICES OF BLACK EDUCATORS Final Repot.pdf

United Way. (2019). Rebalancing the opportunity equation. https://www.unitedwaygt.org/file/2019 OE fullreport FINAL.pdf

Vandenbroeck, M. (2010). Moving beyond anti-bias education: Changing conceptions of diversity and equity in European early childhood education. European Early Childhood Education Research Journal, 15(1), 21-35. https://doi.org/10.1080/13502930601046604 